\title{
Upaya Meningkatkan Kemandirian Belajar Prakarya dan Kewirausahaan dengan Metode Pemberian Tugas (Resitasi) di Kelas XIIK MAN Wates I Kabupaten Kulon Progo
}

\author{
Sihono Setyo Budi \\ MAN Wates I Kabupaten Kulon Progo \\ Jalan Mandung, Desa Pengasih, Kecamatan Pengasih, Kabupaten Kulon Progo \\ sihonosetyobudi@yahoo.co.id
}

\begin{abstract}
This study aims to determine whether the method of giving the task (recitation) can improve the independence of learning in the class XIIK MAN Wates. The subject of this study is students of MAN Wates I Kulon Progo class XIIK as many as 30 students. The data is obtained by using observation sheets and independence test scale, the data analysis using quantitative and qualitative. From the analysis is found that giving task (recitation) method can improve the independence of learning. There is a significant increase between cycle I and cycle II. The average score of self-learning test in the first cycle of 7.4 and on the second cycle test of 7.9, the student activity in doing the Prakarya Dan Kewirausahaan is also increase, 71,4\% in cycle I and $80,7 \%$ in cycle II.
\end{abstract}

Keywords: method of recitation, learning independence

\begin{abstract}
Abstrak
Penelitian ini bertujuan untuk mengetahui apakah Metode Pemberian Tugas (resitasi) dapat meningkatkan kemandirian belajar di kelas XIIK MAN Wates. Subyek penelitian ini adalah siswa MAN Wates I Kabupaten Kulon Progo kelas XIIK sebanyak 30 siswa. Data diperoleh dengan menggunakan lembar obsevasi dan skala test kemandirian, analisa data menggunakan kuantitatif dan kualitatif. Dari analisa ditemukan bahwa Metode Pemberian Tugas (Resitasi) dapat meningkatkan kemandirian belajar. Terlihat terdapat peningkatan yang signifikan antara siklus I dan siklus II. Jumlah skor rata-rata test kemaandirian belajar pada siklus I sebesar 7,4 dan pada test siklus II sebesar 7,9 Aktivitas siswa dalam mengerjakan tugas prakarya dan kewirausahaan juga mengalami peningkatan, yaitu sebesar $71,4 \%$ pada siklus I dan 80,7\% pada siklus II.
\end{abstract}

Kata Kunci : metode resitasi, kemandirian belajar

\section{PENDAHULUAN}

Keberhasilan belajar menjadi dambaan setiap orang baik siswa, orang tua, guru, sekolah, masyarakat, maupun negara. Keberhasilan belajar siswa dipengaruhi oleh berapa faktor, secara garis besar dapat dibedakan menjadi dua macam, yaitu faktor dari dalam diri siswa dan dari luar diri siswa. ${ }^{1}$

Kemandirian dalam belajar adalah suatu perubahan dalam diri seseorang untuk

${ }^{1}$ Sabri, Strategi Belajar Mengajar, Cet ke I (Jakarta: Quantum Teaching, 2005), hal 48 
melakukan aktivitas belajar dengan cara mandiri atas dasar motivasinya sendiri dan merupakan hasil dari pengalaman dan latihan diri sendiri tanpa bergantung pada orang lain untuk menguasai suatu materi tertentu sehingga bisa dipakai untuk memecahkan masalah yang sedang dihadapi. Anak yang memiliki kemandirian yang kuat tidak akan mudah menyerah.

Sikap kemandirian dapat ditunjukkan dengan adanya kemampuan dapat menyelesaikan masalah yang dihadapi dengan tingkah laku. Dengan adanya perubahan tingkah laku maka anak juga memiliki peningkatan dalam berfikir, menganggap bahwa dalam belajar harus bisa mandiri tanpa mengandalkan bantuan dari orang lain terus dan juga tidak menggantungkan belajar dari guru saja, tapi belajar juga bisa dari media cetak, elektronik, alam, atau yang lainnya. pada dasarnya sikap mandiri seseorang tidak terbentuk dengan cara yang mendadak, namun melalui proses sejak masa anak-anak. Dalam perilaku mandiri antara tiap individu tidak sama, kondisi ini dipengaruhi oleh banyak hal.

Kemandirian belajar seseorang adalah suatu bentuk belajar yang berpusat pada kreasi siswa dari kesempatan dan pengalaman penting siswa sehingga ia mampu, percaya diri, memotivasi diri dan sanggup belajar setiap waktu. Kemandirian belajar siswa perlu diupayakan dan dilatih tanpa adanya latihan siswa tidak mampu mandiri dalam melakukan kegiatan belajar secara sendiri kemandirian dapat dicapai jika seorang anak diberi makin banyak dan makin banyak kesempatan untuk menjelajahi, mencoba, dan mengontrol kesalahan-kesalahan sendiri.

Metode resitasi atau penugasan adalah metode penyajian bahan dimana guru memberikan tugas tertentu agar siswa melakukan kegiatan belajar. Masalahnya tugas yang dilaksanakan oleh siswa dapat dilakukan di dalam kelas, dihalaman sekolah, di laboratorium, di perpustakaan, dibengkel, di rumah siswa, atau dimana saja asal tugas itu dapat dikerjakan. ${ }^{2}$

${ }^{2}$ Djamarah, Strategi Belajar Mengajar, edisi Revisi
Metode ini diberikan karena dirasakan bahan pelajaran terlalu banyak, sementara waktu sedikit. Artinya, banyaknya bahan yang tersedia dengan waktu kurang seimbang.Agar bahan pelajaran selesai sesuai batas waktu yang ditentukan, maka metode inilah yang biasanya guru gunakan untuk mengatasinya.Tugas dan resitasi tidak sama dengan pekerjaan rumah (PR), tetapi jauh lebih luas dari itu. Tugas biasanya dilaksanakan dirumah, disekolah, di perpustakaan, dan di tempat lainnya.Tugas dan resitasi merangsang anak untuk aktif belajar, baik secara individual maupun secara kelompok. Karena itu, tugas dapat diberikan secara individual, atau dapat pula secara berkelompok.

Tugas yang dapat diberikan kepada anak didik ada berbagai jenis. Karena itu, tugas sangat banyak macamnya, bergantung pada tujuan yang akan dicapai; seperti meneliti, tugas menyususn laporan (lisan/tulisan), tugas motorik (pekerjaan motorik), tugas dilaboratorium, dan lain-lain. Pembelajaran dengan menggunakan metode penugasan berarti guru memberi tugas tertentu agara siswa melakukan kegiatan belajar.Tugas yang diberikan guru dapat berupa masalah yang harus dipecahkan dan prosedurnya tidak diberitahukan.

Metode penugasan ini dapat mengembangkan kemandirian siswa, merangsang untuk belajar lebih banyak, membina disiplin dan tanggung jawab siswa, dan membina kebiasaan mencari dan mengolah sendiri informasi.

Kekurangan metode ini terletak pada sulitnya mengawasi mengenai kemungkinan siswa tidak bekerja secara mandiri. Dengan metode resitasi sebenarnya mempunyai tujuan yang utama yaitu melatih siswa untuk berdiri sendiri (mandiri) disamping memupuk inisiatif, merangsang motivasi, dan memperoleh pengalaman yang terintegrasi karena tugas maka siswa akan terdorong untuk mengajarkan secara sungguh-sungguh. Dengan metode ini siswa melaksanakan latihan-latihan selama sesuatu dapat lebih mendalam. Dengan pengertian lain,

(Jakarta: Rineka Cipta, 2006), hal 85 
resitasi yang diberikan guru dapat merangsang siswa untuk aktif belajar. Hal ini terjadi, karena siswa memperoleh pengetahuan serta ketrampilan siswa di sekolah melalui kegiatankegiatan diluar sekolah. Dengan demikian siswa dapat mengembangkan daya berpikir, daya kreatif, tanggung jawab dan melatih kemandirian.

Berdasarkan keadaan di atas guru perlu melakukan upaya agar kemandirian belajar siswa dapat meningkat maka penggunaan metode pemberian tugas atau resitasi merupakan salah satu alternatif yang bisa dilakukan, yang akan bermuara pada peningkatan prestasi pula.

Kemandirian belajar adalah kemampuan siswa untuk belajar sendiri tanpa tergantung pada orang lain, mampu mengerjakan tugas rutin secara mandiri, bertanggung jawab atas tindakannya, memiliki kemampuan berinisiatif, mampu mengatasi masalah, percaya diri dan dapat mengambil keputusan dalam bentuk memilih. Siswa yang memiliki kemandirian belajar diharapkan mampu belajar secara aktif baik saat didampingi guru maupun tanpa didampingi guru. Siswa yang mampu belajar mandiri adalah siswa yang dapat mengontrol dirinya sendiri, mempunyai minat dalam mempelajari materi pelajaran, motivasi yang tinggi, yakin akan dirinya, mempunyai orientasi atau wawasan yang luas dan luwes. Kemandirian belajar akan mendorong siswa untuk memiliki rasa ingin belajar dengan alasan bahwa ia yakin akan berhasil dalam proses belajar mengajar sehingga prestasinya tinggi.

Febriana dan Sarbiran (2001), memberikan beberapa indikator kemandirian belajar. Secara lengkap indikator tersebut adalah :(1) mencukupi kebutuhan sendiri, (2) mampu mengerjakan tugas rutin secara mandiri, (3) bertanggungjawab atas tindakannya, (4) memilikinya kemampuan inisiatif, (5) mampu mengatasi masalah, (6) percaya diri, (7) dapat mengambil keputusan dalam bentuk memilih. ${ }^{3}$ Jadi yang dimaksud

${ }^{3}$ Febriana,R \& Sarbiran, Pengaruh kemandirian dan kemampuan menyesuaikan diri terhadap prestasi belajar siswa full day school. Jurnal penelitian dan evaluasi No.4 tahun Ke-3. (Yogyakarta:Pascasarjana dengan kemandirian siswa dalam penelitian ini adalah kemandirian seseorang dalam kegiatan belajarnya. Kemandirian belajar akan terwujud apabila siswa telah memiliki jiwa kemandirian. Seorang siswa yang mandiri secara otomatis akan menumbuhkan kemandirian belajar yang dimilikinya.

Dalam proses belajar mengajar termasuk belajar bidang studi Prakarya dan Kewirausahaan di MAN 1 Wates Kulon Progo, kemandirian belajar sangat menetukan prestasi belajar. Bagaimanapun sempurnanya metode yang digunakan oleh guru, namun jika kemandirian belajar siswa kurang atau tidak ada, maka siswa tidak akan belajar dengan baik akibatnya prestasi belajarnya pun tidak akan tercapai. Penggunaan metode yang tepat akan berpengaruh terhadap kemandirian belajar siswa yang akirnya akan meningkat pula prestasi belajarnya.

Metode resitasi banyak digunakan guru dengan cara memberikan tugas yang harus dilakukan oleh siswa, baik selama diluar kelas maupun di luar kelas. Metode ini memberikan kesempatan belajar bagi siswa diluar kelas. Kesempatan belajar tidak hanya di rumah namun dapat dilakukan di perpustakaan, masjid, atau lingkungan sekitar yang sesuai dengan materi dan tujuan pembelajaran. Pemberian tugas dilakukan untuk memberikan bekal tambahan pengalaman dan pengetahuan kepada siswa. Tugas dapat dilakukan secara individu maupun kelompok. Tugas yang diberikan berkaitan dengan materi yang sedang dipelajari, sesuai kemampuan siswa baik akademik maupun non akademik, jelas prosedur pengerjaannya, dan batas waktu pengerjaannya.

Ada tiga fase yang harus dilalui ketika diberikan tugas oleh guru, yaitu fase pemberian tugas, fase belajar di luar kelas (pelaksanaan tugas), dan fase mempertanggungjawabkan pelaksanaan tugas setelah dikerjakan.

Langkah-langkah yang harus diikuti dalam penggunaan metode pembelajaran tugas antara lain :

Universitas Negeri Yogyakarta.2001 
Fase pemberian tugas, dengan mempertimbangkan: tujuan yang akan dicapai, jenis tugas jelas sehingga anak mengerti apa yang ditugaskan tersebut, sesuai dengan kemampuan siswa, ada petunjuk atau sumber yang dapat membantu pekerjaan siswa, tersedia waktu yang cukup untuk mengerjakan tugas tersebut.

Fase pelaksanaan tugas dalam fase ini anak didik belajar (melaksanakan tugas) sesuai tujuan dan petunjuk-petunjuk guru. Dengan langkah: guru memberikan bimbingan, dorongan sehingga anak mau bekerja, diusahakan atau dikerjakan oleh siswa sendiri, tidak menyuruh orang lain dan dianjurkan agar siswa mencatat hasil-hasil yang dia peroleh dengan baik dan sistematik

Fase mempertanggungjawabkan dalam fase ini anak didik mempertanggungjawabkan hasil belajarnya baik berbentuk laporan lisan maupun tertulis. Karena tugas yang dikerjakan pada akhirnya akan dipertanggung jawabkan maka siswa akan terdorong untuk mengerjakan secara sungguh-sungguh. Dengan metode ini sehingga pengalaman siswa dalam mempelajari sesuatu lebih mendalam. ${ }^{4}$

Dari kajian teori diatas maka peneliti merumuskan hipotesis dengan menggunakan metode pemberian tugas kemandirian belajar siswa dapat meningkat.

\section{METODE PENELITIAN}

Penelitian ini adalah Penelitian Tindakan Kelas (PTK) yang dilakukan secara kolaboratif antara guru mata pelajaran Prakarya dan kewirausahaan dan peneliti yang dilaksanakan di Madrasah Aliyah Negeri I Wates Kulon Progo (MAN I Wates ). Peran guru mata pelajaran Prakarya dan kewirausahaan sebagai kolaborator, sedangkan peneliti sebagai pelaksana pembelajaran. Keduanya terlibat sejak perencanaan, pelaksanaaan, pengamatan hingga refleksi terhadap pembelajaran.

Subyek penelitian ini adalah siswa kelas X IIK MAN Wates I Kulon Progo

\footnotetext{
${ }^{4}$ Suprihatiningrum, Strategi Pembelajaran Strategi dan Aplikasi,Cet ke III (Jogjakarta: Arruzz Media, 2016), hal 292
}

sejumlah 30 siswa yang dipandang peneliti mempunyai kemandirian belajar prakarya dan kewirausahaan yang rendah. Penelitian dilaksanakan di MAN I Wates Jln. Mandung Pengasih Kulon Progo. Penelitian direncanakan 2 siklus sampai indikator keberhasilan tercapai. Setiap siklus terdiri dari 2 pertemuan meliputi: perencanaan, pelaksanaan, observasi, test, refleksi. Pengembangan instrumen penelitian :

\section{Peneliti}

Peneliti merupakan instrumen utama, karena peneliti sekaligus berperan sebagai perencana, pelaksasnan, pengaat, pengumpul data penganalisis data, sekaligus penyususn laporan penelitian.

\section{Lembar Observasi}

Lembar observasi digunakan sebagai panduan peneliti dan observer dalam mengamati dan mencatat segala aktivitas siswa dalam memecahkan masalah selama proses belajar mengajar berlangsung.

\section{Lembar Soal Tes Kemandirian Belajar}

Test bertujuan untuk mengukur kemandirian belajar siswa dalam memecahkan masalah prakarya dan kewirausahaan dan diberikan disetiap akhir siklus. soal test yang telah dikerjakan dianalisis tentang kemandirian belajar siswa menggunakan pedoman penskoran nilai selanjutnya digabungkan. Soal test mempunyai realibilitas 0,95 dan validitas 0,3 $-0,76$.

Data dalam penelitian bersumber dari interaksi dalam pembelajaran keterampilan dan data tindakan belajar atau perilaku belajar. Pengambilan data dilakukan dengan observasi dan lembar soal test kemandirian.

Pada penelitian ini data dianalisis sejak tindakan pembelajaran dilakukan. Data yang diperoleh dalam penelitian berupa hasil catatan di lapangan dan hasil observasi. Setelah itu dilakukan reduksi data yang bertujuan untuk merangkum, memfokuskan, menyerderhanakan dan mentransfer data. Langkah selanjutnya dilakukan analisis data berupa: 


\section{Data Test Kemandirian Belajar Siswa}

Teknis analisis yang digunakan untuk mengukur peningkatan kemaandirian belajar siswa dilaksanakan setiap akir siklus (siklus 1 dan siklus 2). Pada setiap test menghasilkan skor kemanditrian belajar siswa dalam mengerjakan tugas prakarya dan kewirausahaan. dengan skor maksimal 100. Pemberian skor kemandirian belajar siswa didasarkan aspek pada pendapat Febriana dan Sarbiran (2001) meliputi: mencukupi kebutuhan sendiri, mengerjakan tugas rutin secara mandiri, bertanggungjawab atas tindakannya, memilikinya kemampuan inisiatif, mampu mengatasi masalah, percaya diri, dapat mengambil keputusan dalam bentuk memilih.

Kemudian diperoleh jumlah skor, dan ditentukkan skor rerata tiap siklus dengan menjumlahkan semua skor siswa kemudian membaginya dengan jumlah siswa yang mengikuti test.

$$
\text { Dengan Formula }=\frac{\text { jumlah skor seluruh siswa }}{\text { jumlah siswa }}
$$

(Rumus 1)

Kriteria test kemandirian belajar siswa dalam mengerjakan tugas Prakarya dan kewirausahaan yang ditunjukkan pada Tabel 1.

Tabel 1. Kriteria test kemandirian belajar siswa dalam mengerjakan tugas Prakarya dan

Kewirausahaan (KK)

\begin{tabular}{ll}
\hline \multicolumn{1}{c}{ Rentang Nilai } & \multicolumn{1}{c}{ Kriteria } \\
\hline $81<\mathrm{KK} \leq 100$ & Sangat Baik \\
$61<\mathrm{KK} \leq 80$ & Baik \\
$41<\mathrm{KK} \leq 60$ & Cukup \\
$21<\mathrm{KK} \leq 40$ & Kurang \\
$0<\mathrm{KK} \leq 20$ & Sangat Kurang \\
\hline
\end{tabular}

\section{Data Observasi Aktivitas Siswa}

Data observasi aktivitas siswa dianalisis dengan mendiskripsikan kegiatan belajar kelompok yang terdiri dari 5 orang dengan menggunakan lembar observasi aktivitas siswa dengan aspek sebagai berikut: Aktif mencukupi kebutuhan bahan dan alat dalam mengerjakan tugas; Aktif mengerjakan tugas; Bertanggungjawab atas tindakannya dan bekerja sama; Memilikinya kemampuan inisiatif; Aktif mengatasi masalah; Percaya diri dalam mengerjakan tugas; Aktif berdiskusi dan mengambil keputusan dalam bentuk memilih.

dengan ketentuan:

skor 1 : tidak ada siswa yang melaksanakan aktivitas, skor 2: siswa yang melaksanakan aktivitas 1-2, skor 3: siswa yang melaksanakan aktivitas 3-4, skor 4: siswa yang melaksanakan aktivitas 5-6.

Penilaian dapat dilihat dari hasil skor pada lembar observasi, persentase skor diperoleh pada lembar observasi untuk menentukan besar aktivitas siswa dalam mengikuti proses pembelajaran. Untuk setiap siklus persentase diperoleh dengan rerata persentase keaktifan siswa pada tiap pertemuan pembelajaran berkelompok. Formulasi persentase banyaknya siswa yang aktif dalam mengerjakan tugas Prakarya dan kewirausahaan adalah:

$\frac{\text { jumlah skor }}{\text { jumlah kelompok x skor maksimum x jumlah aspek }} \times 100 \%$

(Rumus 2)

dengan kriteria yang ditunjukkan pada Tabel 2.

Tabel 2. Persentase banyaknya siswa yang aktif dalam mengerjakan tugas (AS)

\begin{tabular}{ll}
\hline \multicolumn{1}{c}{ Rentang Persentase } & \multicolumn{1}{c}{ Kriteria } \\
\hline $80<\mathrm{AS} \leq 100$ & Sangat Baik \\
$60<\mathrm{AS} \leq 80$ & Baik \\
$40<\mathrm{AS} \leq 60$ & Cukup \\
$20<\mathrm{AS} \leq 40$ & Kurang \\
$0<\mathrm{AS} \leq 20$ & Sangan Kurang \\
\hline
\end{tabular}

\section{Data Observasi Pembelajaran}

Data observasi pelaksanaan pembelajaran dianalisis dengan mendiskripsikan pelaksanaan pembelajaran di dalam kelas dengan menggunakan lembar observasi pembelajaran dengan aspek sebagai berikut: tujuan yang akan dicapai, jenis tugas jelas dan tepat, sesuai 
dengan kemampuan siswa, ada petunjuk atau sumber, sediakan waktu yang cukup, diberikan bimbingan atau pengawasan, diberikan dorongan dikerjakan oleh siswa, siswa mencatat hasil, dilaporkan oleh siswa baik lisan atau tertulis, ada tanya jawab diskusi kelas, penilaian hasil pekerjaan.

Dengan kriteria penilaian sebagai berikut: skor 3 : pelaksanaan pembelajaran baik, skor 2 : pelaksanaan pembelajaran kurang baik, Skor 1: pelaksanaanpembelajaran tidak baik. Cara menghitung skor pelaksanaan pembelajaran adalah sebagai berikut:

$\begin{aligned} & \text { Persentase pelaksanaan } \\ & \text { pembelajaran }\end{aligned}=\frac{\text { jumlah skor }}{\text { skor maksimum }} \times 100 \%$

Tabel 3. Kriteria pelaksanaan pembelajaran (PP)

\begin{tabular}{lc}
\hline \multicolumn{1}{c}{ Rentang Persentase } & Kriteria \\
\hline $67 \%<\mathrm{PP} \leq 100 \%$ & Baik \\
$33 \%<\mathrm{PP} \leq 67 \%$ & Cukup \\
$0 \%<\mathrm{PP} \leq 33 \%$ & Kurang \\
\hline
\end{tabular}

Indikator Keberhasilan Penelitian: Terjadi peningkatan kemandirian belajar dari hasil test pada siklus 1 ke siklus 2, rerata skor kemandirian belajar siswa pada akhir siklus ke dua baik, aktivitas siswa dalam mengerjakan tugas pada siklus kedua mempunyai kriteria baik, pelaksanaan pembelajaran dengan model pemberian tugas (resitasi) mempunyai kategori baik atau $67 \%$ langkah-langkahnya tercapai

\section{HASIL DAN PEMBAHASAN Siklus I}

Pembelajaran pada siklus I dilaksanakan selama dua kali pertemuan dan diakhiri dengan test 1 . Tindakan yang dilakukan pada siklus 1 ini meliputi:

\section{Perencanaan}

Pada tahap ini peneliti menyusun RPP dan LKS serta soal test, Instrumen observasi aktivitas siswa dan instrumen observasi pembelajaran yang digunakan sebagai catatan selama proses belajar mengajar berlangsung.

\section{Pelaksanaan Tindakan dan Observasi}

Berdasarkan pengamatan peneliti dan Observer selama pembelajaran berlangsung dapat didiskripsikan sebagai berikut:

\section{Pertemuan Pertama}

Pelaksanaan pembelajaran pada siklus pertama dengan materipemasangan komponen resistor dan capasitor pada tuner FM. Pada siklus ini siswa masih belum terbiasa dengan situasi kelas yang diamati. Guru memulai pembelajaran dengan mengingatkan kembali materi sebelumnya, selanjutnya memberikan motivasi dan menjelaskan cara memasang komponen resistor dan capasitor. Kemudian membentuk kelompok menjadi 6 kelompok dengan anggota 5 orang, diberikan LKS untuk mengerjakan tugas yang ada di LKS. Guru mengawasi jalannya kerja kelompok dan observer mengamati sekaligus mencatat aktivitas siswa dan pembelajaran yang terjadi.

Pada awal kelihatan masih gaduh dan tidak terkoordinasi dengan baik kemudian dengan bimbingan guru siswa dapat memulai mengerjakan LKS .Setelah siswa menyelesaikan tugas guru meminta salah satu perwakilan kelompok mempresentasikan hasilnya prakteknya di depan kelas. Setelah semua kelompok mempresentasikan hasil pekerjaannnya guru membahasnya selanjutnya di buat kesimpulan. Selanjutnya guru memberikan pesan bahwa pertemuan yang akan akan datang dilaksanakan tes 1 .

Pertemuan kedua

Pelaksanaan pembelajaran pada pertemuan kedua dengan materi mengerjakan skala test kemandirian dengan alokasi waktu 45 menit. Peneliti bersama observer membagikan lembaran soal kemudian siswa mengerjakan.

\section{Refleksi}

Dari hasil diskusi yang dilakukan oleh peneliti dan observer terhadap pelaksanaan pembelajaran siklus I beberapa hambatan dan kekurangan antara lain: Masih banyak siswa 
yang belum mampu dalam mengerjakan tugas yang diberikan guru terutama dalam memasang komponen resistor siswa masih perlu bimbingan. Sebagian siswa kurang aktif mengerjakan tugas merangkai komponen dan tergantung teman lain dalam memasang komponen. Siswa masih banyak yang tidak mau bertanya pada guru. Takut mempresentasikan di depan kelas.

Guru bersama observer berdiskusi untuk memberikan solusi terhadap permasalahan yang terjadi pada siklus I untuk dilksanakan pada siklus ke II dengan alternatif sebagai berikut:

Memberikan cara membaca kode komponen resistor, dengan tabel kode warna dengan harapan dapat meningkatkan kemampuan siswa dalam membaca kode komponen resistor.

Memberikan motivasi dan pujian agar siswa tidak tergantung oleh teman lain, mengontrol jalannya praktikum (pemasanagan komponen) dan menjelaskan betapa pentingnya mengetahui kode warna resistor dalam keterampilan elektronika ini.

Guru senantiasa memberikan umpan balik agar siswa termotivasi untuk bertanya, dan memberikan tanggapan setiap pertanyaan siswa.

Memberian hadiah nilai bagi siswa yang mampu mempresentasikan di depan kelas.

Berdasarkan hasil pengamatan pada pertemuan pertama siswa merasa kesulitan dalam memahami cara membaca kode komponen resistor dan capasitor. Siswa belum terbiasa membaca kode komponen apalagi memasang (menyoder). Meskipun di awal guru sudah memberikan apersepsi ketika dihadapkan LKS siswa merasa kesulitan untuk menyelesaikan tugas tersebut. Siswa terlihat tidak tahu apa yang harus dikerjakan untuk menyelesaikan tugas tersebut. Hal ini terlihat pada diskusi berlangsung siswa masih banyak mendapat perhatian guru dalam menyelesaikan tugas. Proses kerja kelompok masih belum efektif, berbicara sendiri, dan enggan bertanya pada guru terhadap tugas yang diberikan. Saat presentasipun masih tidak berani untuk maju di depan kelas. Persentase hasil observasi pada pertemuan pertama banyaknya siswa yang aktif seperti Tabel 4.
Tabel 4. Persentase banyaknya siswa yang aktif dalam mengerjakan tugas pada siklus I

\begin{tabular}{lcc}
\hline Aspek yang diamati & Persentase & Kategori \\
\hline $\begin{array}{l}\text { Aktif mencukupi kebutuhan } \\
\text { bahan dan alat dalam } \\
\text { mengerjakan tugas }\end{array}$ & 90 & $\begin{array}{c}\text { Sangat } \\
\text { baik }\end{array}$ \\
$\begin{array}{l}\text { Aktif mengerjakan tugas } \\
\text { Bertanggungjawab } \\
\text { atas tindakannya dan bekerja }\end{array}$ & 70 & $\begin{array}{c}\text { baik } \\
\text { baik }\end{array}$ \\
$\begin{array}{l}\text { sama } \\
\text { Memilikinya kemampuan } \\
\text { inisiatif }\end{array}$ & 65 & baik \\
$\begin{array}{l}\text { Aktif mengatasi masalah } \\
\text { Percaya diri dalam } \\
\text { mengerjakan tugas }\end{array}$ & 70 & baik \\
$\begin{array}{l}\text { Aktif berdiskusi dan } \\
\text { mengambil keputusan dalam } \\
\text { bentuk memilih }\end{array}$ & 70 & baik \\
\hline \multicolumn{1}{c}{ Rerata } & 60 & baik \\
\hline
\end{tabular}

\section{Observasi Pelaksanaan pembelajaran pada pertemuan Pertama}

Observasi pelaksanaan mengajar menunjukkan bahwa guru sudah melaksanakan urutan mengajar dengan metode penugasan (resitasi) yaitu: telah menyampaikan tujuan pembelajaran yang akan dicapai, memb9hherikan tugas yang jelas, ada petunjuknya ,sesuai dengan kemampuan siswa dan waktu pengerjaan yang cukup. Guru telah memberikan bimbingan, dan motivasi siswa dan siswa mengerjakan sendiri sesuai kelompok kerjanya. Guru juga telah meminta hasilnya dilaporkan dan didiskusikan serta dinilai. Dari tabel disimpulkan bahwa pelaksanaan pembelajaran dengan menggunakan metode resitasi sudah terlaksana $88,8 \%$ atau kategori baik.

Tabel 5. Observasi Pelaksanaan pembelajaran

\begin{tabular}{cccc} 
Siklus & Pertemuan Ke & Persentase & Keterangan \\
\hline I & $1 / 2$ & 88,8 & Baik \\
\hline
\end{tabular}

\section{Siklus II}

Rancangan pada siklus II hampir sama dengan siklus I akan tetapi dilakukan perbaikan perbaikan dengan rencana tindakan sebagai berikut:

Lebih memaksimalkan contoh real tekait materi yang diberikan yaitu membaca kode 
pada komponen elektronika sehingga dapat meningkatkan kemampuan siswa dalam memasang komponen .

Memberikan motivasi akan pentingnya kode warna, kode angka, dalam komponen elektronika sehingga dalam kehidupan seharihari siswa mampu memecahkan sendiri permasalahan yang terjadi.

Guru lebih aktif mengontrol jalannya praktikum dan selalu memberikan umpan balik terhadap setiap pertanyaan yang diberikan siswa.

Memberikan pujian dan nilai plus kepada siswa yang mampu menjawab pertanyaan dengan baik dan mau mempresentasikan hasil pekerjaan di depan kelas.

Pada Siklus II ini direncana dengan dua kali pertemuan seta diakhiri dengan test kemandirian yang berguna untuk mengukur tingkat kemandirian siswa . Materi yang akan dibahas pada siklus ini adalah melanjutkan pemasangan komponen pada rangkaian tuner FM dengan tindakan sebagai berikut:

\section{Pertemuan Pertama}

Pelaksanaan pembelajaran pertama pada siklus II dengan materimelanjutkan pemasangan komponen dirangkaian Tuner FM. Pada siklus ini peneliti bersama observer sepakat mengubah metode penugasan menjadi turnamen dengan memberikan hadiah nilai plus bagi kelompok yang mengerjakan dengan cepat dan benar. Dan nilai plus bagi siswa yang mau mempresentasikan dengan benar di depan kelas. Metode ini dengan harapan siswa berlomba lomba menyelesaikan setiap permasalahan dengan benar dan cepat.

Guru memulai pembelajaran dengan mengingatkan kembali materi di pertemuan sebelumnya, selanjutnya memberikan motivasi dan menjelaskan permasalahan elektronika yang ada di kehidupan sehari-hari.Kemudian membentuk kelompok menjadi 6 kelompok dengan anggota 5 orang, diberikan LKS untuk mengerjakan tugas yang ada di LKS. Guru mengawasi jalannya mengerjakan tugas dan observer mengamati sekaligus mencatat aktivitas siswa dan pembelajaran yang terjadi.
Sesuai rencana peneliti bersama observer pada pembelajaran ini diubah dari penugasan biasa menjadi turnamen dengan memberikan penghargaan nilai plus kepada siswa yang cepat menyelesaiakan tugas, mau mempresentasikan di depan kelas. Selain itu lebih mengontrol jalannya diskusi dan menanggapi setiap pertanyaaan yang diajukan siswa. Kelompok yang telah menyelesaikan terlebih dahulu diberikan kesempatan untuk mempresentasikan terlebih dahulu jika jawaban benar maka kelompok itu di berikan hadiah nilai plus. Setelah semua kelompok mempresentasikan hasil pekerjaannnya guru membahasnya selanjutnya di buat kesimpulan. Selanjutnya guru memberikan pesan bahwa pertemuan yang akan adatang dilksanakan test ke - 2 untuk mengukur tingkat kemandirian belajar siswa.

\section{Pertemuan kedua}

Pelaksanaan pembelajaran pada pertemuan kedua dengan materi test 2 dengan alokasi waktu 45 menit dengan soal pilihan ganda. Peneliti bersama observer membagikan lembaran soal kemudian siswa mengerjakan.

\section{Refleksi}

Dari hasil diskusi yang dilakukan oleh peneliti dan observer terhadap pelaksanaan pembelajaran siklus II terdapat banyak peningkatan dalam pemasangan komponen elektronika antara lain: Siswa mampu mengerjakan tugas memasang komponen dioda dan transistor dengan baik. Siswa lebih aktif megerjakan tugas dan saling bekerja sama dengan temanlain dalam menyofder komponen. Siswa tidak tidak lagi malu bertanya pada guru. Siswa berani mempresentasikan hasil pekerjaannya di depan kelas.

Berdasarkan hasil observasi dan test secara keseluruhan kemampuan siswa dalam memasang komponen dioda dan transistor pada siklus II ini mengalami peningkatan jika dibandingkan dengan siklus I. Dengan demikian secara keseluruhan hasil penelitian ini baik observasi maupun test memenuhi kriteria yang telah ditetapkan. 


\section{Observasi pada pertemuan pertama}

Berdasarkan hasil pengamatan pada pertemuan pertama siswa merasal lebih aktif dan antusias dalam mengerjakan tugas yang diberikan karena adanya penghargaan yang diberikan. Tanpa diminta siswa lebih semangat untuk mempresentasikan jawabanya di depan kelas. Dengan demikian diskusi lebih optimal dan siswa tidak takut lagi bertanya pada guru. Secara keseluruhan aktivitas siswa dalam mengerjakan tugas mulai meningkat, seperti pada Tabel 6.

Tabel 6. Persentase banyaknya siswa yang aktif dalam mengerjakan tugas pada siklus II

\begin{tabular}{lcc}
\hline Aspek yang diamati & Persentase & Kategori \\
\hline $\begin{array}{l}\text { Aktif mencukupi kebutuhan } \\
\text { bahan dan alat dalam } \\
\text { mengerjakan tugas }\end{array}$ & 90 & $\begin{array}{c}\text { Sangat } \\
\text { baik }\end{array}$ \\
$\begin{array}{l}\text { Aktif mengerjakan tugas } \\
\text { Bertanggungjawabatas } \\
\text { tindakannya dan bekerja }\end{array}$ & 80 & $\begin{array}{l}\text { baik } \\
\text { baik }\end{array}$ \\
$\begin{array}{l}\text { sama } \\
\text { Memilikinya kemampuan }\end{array}$ & 75 & baik \\
$\begin{array}{l}\text { inisiatif } \\
\begin{array}{l}\text { Aktif mengatasi masalah } \\
\text { Percaya diri dalam } \\
\text { mengerjakan tugas }\end{array}\end{array}$ & 80 & baik \\
$\begin{array}{l}\text { Aktif berdiskusi dan } \\
\text { mengambil keputusan dalam } \\
\text { bentuk memilih }\end{array}$ & 80 & baik \\
\hline \multicolumn{1}{c}{ Rerata } & 75 & baik \\
\hline
\end{tabular}

\section{Observasi Pelaksanaan pembelajaran pada pertemuan Pertama Siklus II}

Pada tabel 7 terlihat pelaksanaan mengajar menunjukkan bahwa guru sudah melaksanakan urutan mengajar dengan metode penugasan (resitasi) yaitu: telah menyampaikan tujuan pembelajaran yang akan dicapai, memberikan tugas yang jelas, ada petunjuknya, sesuai dengan kemampuan siswa dan waktu pengerjaan yang cukup. Guru telah memberikan bimbingan, dan motivasi siswa dan siswa mengerjakan sendiri sesuai kelompok kerjanya. Guru juga telah meminta hasilnya dilaporkan dan didiskusikan serta dinilai. Terlihat bahwa rencana pada pembelajaran ini diubah dari penugasan biasa menjadi turnamen dengan memberikan penghargaan nilai plus kepada siswa yang cepat menyelesaiakan tugas, mau mempresentasikan di depan kelas telah berhasil. Dapat disimpulkan bahwa pelaksanaan pembelajaran dengan menggunakan metode resitasi sudah terlaksana $95 \%$ atau kategori baik.

Tabel 7. Observasi Pelaksanaan pembelajaran pada pertemuan pertama Siklus II

\begin{tabular}{cccc}
\hline Siklus & Pertemuan Ke & Persentase & Keterangan \\
\hline 2 & $1 / 2$ & 95 & Baik \\
\hline
\end{tabular}

Observasi pelaksanaan mengajar menunjukkan bahwa guru sudah melaksanakan urutan mengajar dengan metode penugasan (resitasi) yaitu: telah menyampaikan tujuan pembelajaran yang akan dicapai, memberikan tugas yang jelas, ada petunjuknya, sesuai dengan kemampuan siswa dan waktu pengerjaan yang cukup. Guru telah memberikan bimbingan, dan motivasi siswa dan siswa mengerjakan sendiri sesuaikelompok kerjanya. Guru juga telah meminta hasilnya dilaporkan dan didiskusikan serta dinilai. Dari tabel disimpulkan bahwa pelaksanaan pembelajaran dengan menggunakan metode resitasi sudah terlaksana $95 \%$ atau kategori baik.

Pada tabel 8 telihat dengan menggunakan metode resistasi terjadi peningkatan prosetase siswa yang aktif dalam mengerjakan tugas pada siklus I sebesar $71,4 \%$ menjadi $80,7 \%$ pada siklus II.

Tabel 8. Persentase banyaknya siswa yang aktif dalam mengerjakan tugas pada siklus I dan Siklus II

\begin{tabular}{lcc}
\hline \multicolumn{1}{c}{ Siklus } & Persentase & Kategori \\
\hline Siklus I & 71,4 & baik \\
Siklus II & 80,7 & baik \\
\hline Keterangan & \multicolumn{2}{c}{ Terjadi peningkatan } \\
\hline
\end{tabular}

Rerata prosentase hasil test siklus I dan Siklus II terjadi peningkatan. Pada tabel 9 telihat dengan menggunakan metode resistasi terjadi peningkatan rerata skor pada siklus I sebesar 7,4 menjadi 7,9 pada siklus II. 
Tabel 9. Skor test kemandirian belajar siswa pada siklus I dan SiklusII

\begin{tabular}{llc}
\hline \multicolumn{1}{c}{ Siklus } & Skor & Kategori \\
\hline Siklus I & 7,4 & Baik \\
Siklus II & 7,9 & Baik \\
\hline \multicolumn{1}{c}{ Keterangan } & \multicolumn{2}{c}{ Terjadi peningkatan } \\
\hline
\end{tabular}

Observasi pelaksanaan mengajar pada siklus I dan Siklus II.

Pada tabel 10 terlihat pelaksanaan mengajar menunjukkan perbaikan dari siklus I ke siklus II. Pada siklus I $88.8 \%$ mengalami peningkatan pada siklus II sebesar $95 \%$, ini menunjukkan bahwa guru sudah berhasil dalam melaksanakan urutan mengajar dengan metode penugasan (resitasi).

Tabel 10. Pelaksanaan mengajar pada siklus I dan Siklus II

\begin{tabular}{cccc}
\hline Siklus & Pertemuan Ke & Persentase & Keterangan \\
\hline 1 & $1 / 2$ & 88,8 & Baik \\
2 & $3 / 4$ & 95 & Baik \\
\hline \multicolumn{2}{c}{ Rerata } & 91,9 & Baik \\
\hline
\end{tabular}

\section{PEMBAHASAN}

Dari diskripsi hasil penelitian yang telah diuraikan di atas dapat diketahui bahwa pembelajaran prakarya dan kewirausahaan dengan menggunakan model penugasan (resitasi) dapat meningkatkan kemandirian belajar siswa kelas X IIK di MAN Wates I.

Pada gambar 1 terlihat skor rata-rata test yang diperoleh siswa pada siklus I dan siklus II. Jumlah skor rata-rata test kemandirian belajar

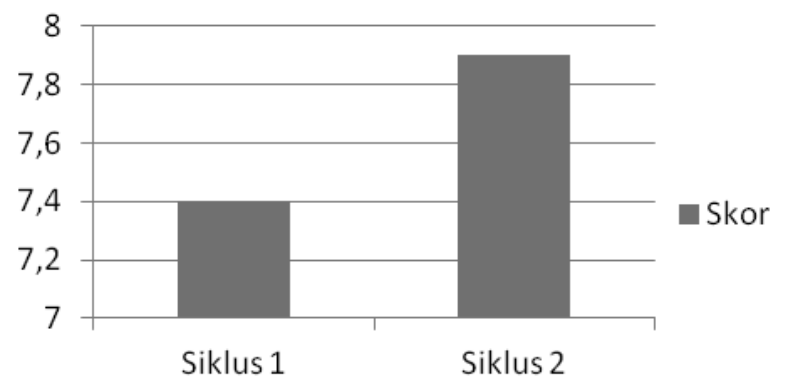

Gambar 1.Skor test kemandirian

siswa dalam mengerjakan tugas prakarya dan kewirausahaan pada siklus I sebesar 7,4 dengan kategori baik dan pada test siklus II menunjukkan peningkatan sebesar 7,9 dengan kategori sangat baik.

Pada gambar 2 terlihat bahwa pembelajaran prakarya dan kewirausahaan dengan menggunakan model penugasan (resitasi) telah dilaksanakan guru dengan baik pada siklus I sebesar $88,8 \%$ dan pada siklus II sebesar $95 \%$ dengan rata-rata 91,9\%. Artinya 91,9\% langkah - langkah pembelajaran dengan metode resitasi telah terlaksana disetiap pertemuan.

Hal ini terlihat dari skor rata-rata test yang diperoleh siswa pada siklus I dan siklus II. Jumlah skor rata-rata test kemandirian belajar siswa dalam mengerjakan tugas prakarya dan kewirausahaan pada siklus I sebesar 7,4 dengan kategori baik dan pada test siklus II menunjukkan peningkatan sebesar 7,9 dengan kategori sangat baik.

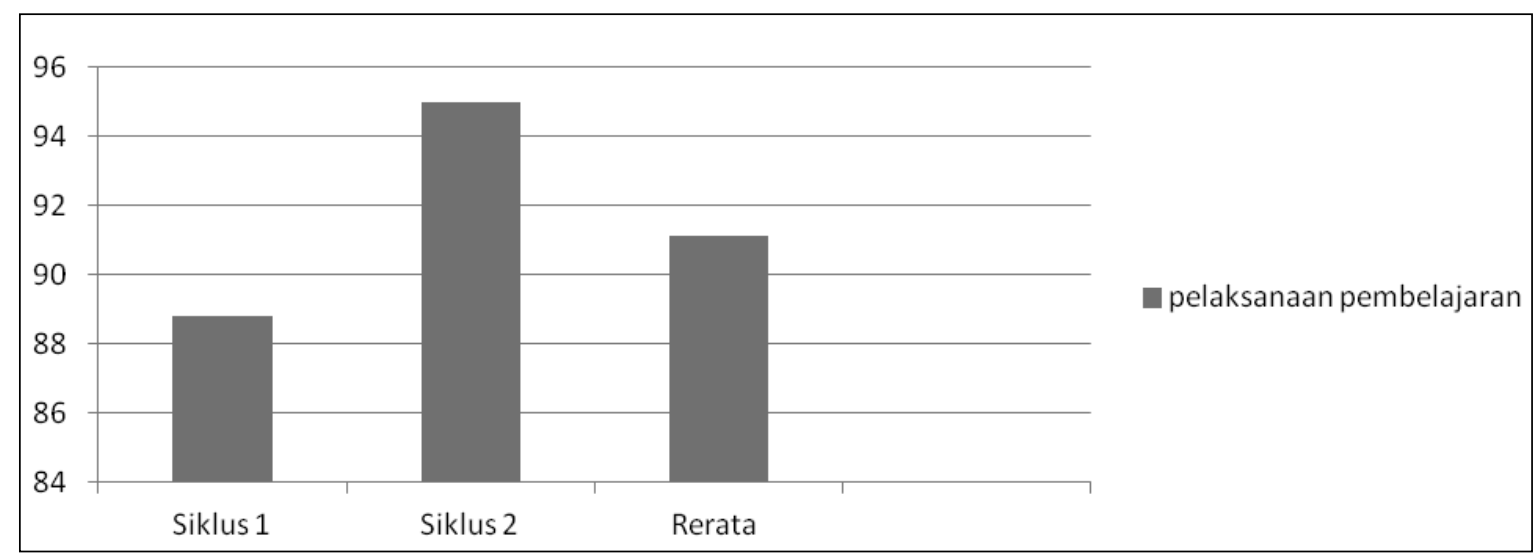

Gambar 2. Pelaksanaan pembelajaran

60 | LITERASI, Volume IX, No. 12018 


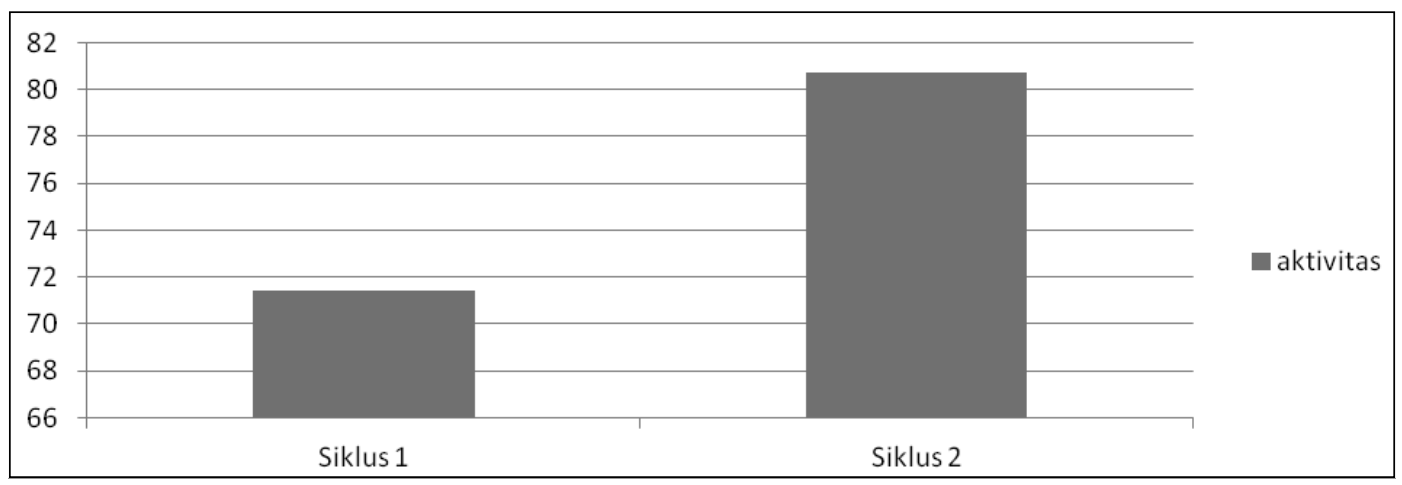

Gambar 3. Aktivitas siswa

Secara keseluruhan pembelajaran prakarya dan kewirausahaan dengan menggunakan model penugasan (resitasi) telah dilaksanakan guru dengan rata-rata 91,9\% langkah - langkah telah terlaksana disetiap pertemuan. Seperti terlihat pada tabel berikut.

Skor rata-rata tiap aspek kemandirian belajar siswa dalam dalam mengerjakan tugas prakarya dan kewirausahaan juga mengalami peningkatan. Pada siklus I aspek mencukupi kebutuhan bahan dan alat dalam mengerjakan tugas sebesar $90 \%$, aspek mengerjakan tugas $70 \%$, aspek tanggungjawab atas tindakannya dan bekerja sama $75 \%$, aspek memilikinya kemampuan inisiati $65 \%$, aspek mengatasi masalah $70 \%$, aspek Percaya diri dalam mengerjakan tugas $70 \%$ dan aspek berdiskusi dan mengambil keputusan $60 \%$ skor rerata $71,4 \%$. Sedangkan pada siklus II aspek mencukupi kebutuhan bahan dan alat dalam mengerjakan tugas sebesar $90 \%$, aspek mengerjakan tugas $80 \%$, aspek tanggungjawab atas tindakannya dan bekerja sama $85 \%$, aspek memilikinya kemampuan inisiati 75\%, aspek mengatasi masalah $80 \%$, aspek Percaya diri dalam mengerjakan tugas $80 \%$ dan aspek berdiskusi dan mengambil keputusan $75 \%$ skor rerata $80,7 \%$ Atau dapat dikatakan bahwa pada siklus I dari 30 orang siswa hanya $71,4 \%$ (21 orang) yang mempunyai kategori aktif mengerjakan tugas prakarya dan kewirausahaan dengan baik dan pada siklus II dari 30 orang siswa $80,7 \%$ (24,3 orang) yang mempunyai kategori aktif mengerjakan tugas prakarya dan kewirausahaan dengan baik.
Aktivitas siswa dalam mengerjakan tugas prakarya dan kewirausahaan mengalami peningkatan, yaitu sebesar $71,4 \%$ pada siklus I dan $80.7 \%$ pada siklus II. Ini memenuhi indikator keberhasilan yaitu rata-rata aktivitas siswa setiap aspek dalam kategori baik.

Pada gambar 3. skor rata-rata tiap aspek kemandirian belajar siswa dalam dalam mengerjakan tugas prakarya dan kewirausahaan juga mengalami peningkatan. Pada siklus I aspek mencukupi kebutuhan bahan dan alat dalam mengerjakan tugas sebesar $90 \%$, aspek mengerjakan tugas $70 \%$, aspek tanggungjawab atas tindakannya dan bekerja sama $75 \%$, aspek memilikinya kemampuan inisiati $65 \%$, aspek mengatasi masalah 70\%, aspek Percaya diri dalam mengerjakan tugas $70 \%$ dan aspek berdiskusi dan mengambil keputusan $60 \%$ skor rerata $71,4 \%$. Sedangkan pada siklus II aspek mencukupi kebutuhan bahan dan alat dalam mengerjakan tugas sebesar $90 \%$, aspek mengerjakan tugas $80 \%$, aspek tanggungjawab atas tindakannya dan bekerja sama $85 \%$, aspek memilikinya kemampuan inisiati $75 \%$, aspek mengatasi masalah $80 \%$, aspek Percaya diri dalam mengerjakan tugas $80 \%$ dan aspek berdiskusi dan mengambil keputusan 75\% skor rerata $80,7 \%$ Atau dapat dikatakan bahwa pada siklus I dari 30 orang siswa hanya $71,4 \%$ (21 orang) yang mempunyai kategori aktif mengerjakan tugas prakarya dan kewirausahaan dengan baik dan pada siklus II dari 30 orang siswa $80,7 \%$ (24,3 orang) yang mempunyai kategori aktif mengerjakan tugas prakarya dan kewirausahaan dengan baik . 
Aktivitas siswa dalam mengerjakan tugas prakarya dan kewirausahaan mengalami peningkatan, yaitu sebesar $71,4 \%$ pada siklus I dan $80.7 \%$ pada siklus II. Ini memenuhi indikator keberhasilan yaitu rata-rata aktivitas siswa setiap aspek dalam kategori baik .

Berdasarkan pembahasan di atas bahwa metode penugasan ini dapat mengembangkan kemandirian siswa, merangsang untuk belajar lebih banyak, membina disiplin dan tanggung jawab siswa, atau dapat disimpulkan bahwa kemandirian belajar meningkat dengan menggunakan model pembelajaran pemberian tugas (resistasi).

\section{KESIMPULAN}

Dengan menggunakan motode penugasan (resitasi) dapat meningkatkan kemandirian belajar siswa kelas X IIK MAN Wates I dalam mengerjakan tugas prakarya dan kewirausahaan. Metode resitasi melatih siswa untuk mandiri disamping memupuk inisiatif, merangsang motivasi, dan memperoleh pengalaman yang terintegrasi karena tugas maka siswa akan terdorong untuk mengajarkan secara sungguhsungguh. Dengan metode ini siswa melaksanakan latihan-latihan selama sesuatu dapat lebih mendalam. Dengan pengertian lain, resitasi yang diberikan guru dapat merangsang siswa untuk aktif belajar. Hal ini terjadi, karena siswa memperoleh pengetahuan serta ketrampilan siswa di sekolah melalui kegiatan-kegiatan diluar sekolah. Dengan demikian siswa dapat mengembangkan daya berpikir, daya kreatif, tanggung jawab dan melatih kemandirian.

Hal ini terlihat dari skor rata-rata test yang diperoleh siswa pada siklus I dan siklus
II megalami peningkatan. Skor rata-rata test kemandirian belajar siswa dalam mengerjakan tugas prakarya dan kewirausahaan pada siklus I sebesar 7,4 dan terjadi peningkatan sebesar 7,9 pada test siklus II.

Dengan menggunakan motode penugasan (resitasi) dapat meningkatkan kemandirian belajar siswa kelas XIIK MAN Wates I dalam mengerjakan tugas prakarya dan kewirausahaan

\section{DAFTAR PUSTAKA}

Djamarah, Stategi belajar Mengajar, (Jakarta: Rineka Cipta, 2006)

Febriana, R \& Sarbiran, Pengaruh kemandirian dan kemampuan menyesuaikan diri terhadap prestasi belajar siswa full day school. Jurnal penelitian dan evaluasi No.4 tahun Ke-3. (Yogyakarta: Pascasarjana Universitas Negeri Yogyakarta, 2001)

Haryono, A. Belajar mandiri konsep dan penerapannya; dalam sistem pendidikan dan pelatihan terbuka/jarak jauh. Jurnal pendidikan terbuka dan jarak jauh, (Jakarta: Universitas Terbuka, 2001)

Marsudi, Perkembangan Peserta Didik. (Surakarta: Muhammadiyah University Press, 2008).

Purwoto, Srategi Pembelajaran Matematika. (Surakarta : Sebelas Maret

University Press, 2003)

Sabri, A. Strategi Belajar Mengajar, (Jakarta : Quantum Teaching, 2005)

Suprihatiningrum, Strategi Pembelajaran Strategi dan Aplikasi, (Jogjakarta: Arruzz Media, 2016)

Tirtaraharja, Umar, PengantarPendidikan, (Jakarta: Rineka Cipta, 2000) 